PUENTES DE PAPEL SOBRE EL OCÉANO. UNA CORRESPONDENCIA ENTRE GALICIA, BRASIL Y ARGENTINA (1919-1977). CARACTERISTICAS FORMALES Y ASPECTOS ECONÓMICOS

Domingo L. González Lopo

Cátedra UNESCO sobre Migracións /

Universidade de Santiago de Compostela 

"Hijo queridísimo, cuando recibas una carta de tu amigo, no dudes en abrazarla como si de él mismo se tratara. Porque los ausentes tienen como su segundo consuelo el abrazar las cartas del que aman, si éste no se halla presente". ${ }^{1}$

(Carta de San Isidoro de Sevilla a San Braulio de Zaragoza)

\section{A MODO DE INTRODUCCIÓN}

No es extraño que muchos historiadores aludan en la introducción de sus estudios a los infortunios que, con el paso del tiempo, sufrió la documentación que utilizan y suele ser lugar común que se lamenten por las desgraciadas pérdidas causantes de lagunas imposibles de llenar. Tal vez, en medio de tanta compunción, seamos quienes hemos trabajado con correspondencia familiar la excepción a tan inexorable regla, porque buena parte de nuestros estudios son el resultado de un golpe de fortuna; y éste que aquí se presenta no se escapa a la norma. Para consuelo de dolientes y esperanza de futuros desengañados, no será ocioso narrar su gestación. Hace unos cuatro años una persona allegada solicitó mis servicios para buscar unos documentos; había comprado toda la herencia de una familia ya extinguida en la parroquia a unos parientes lejanos que residían en Brasil y necesitaba encontrar el inventario de bienes raíces, que sospechaba podía encontrarse en medio de un enorme revoltijo de papeles. La acompañé a una casa en cuyo desván me señaló un baúl, que sin duda había cruzado en tiempos el Atlántico en las bodegas de un vapor - y seguramente más de una vez-, pidiéndome que buscase. Estaba a rebosar de documentos, pero no fue difícil encontrar lo que quería; luego, por curiosidad, ojeé el resto y pude comprobar, para mi sorpresa, que eran cartas, decenas y decenas de car-

${ }^{1}$ Cit. por M. Carriedo Tejedo, "Libros, documentos y clérigos (en la época de San Rosendo)", Rudesindus. Miscelánea de Arte y Cultura, 3 (2008), p. 57. 
tas, fechadas a lo largo de un periodo muy prolongado de tiempo y que se habían guardado durante décadas, en confuso amasijo, pero sin duda con devoción. Inconsistentes amarras que habían mantenido próximos a los que estaban lejos; presentes a los que ya no se vería más. No faltaban ni los sobres, donde la mayor parte de las misivas se conservaban respetando su doblez original. Algunas habían sido mutiladas tardíamente para sacarles los sellos con que las franquearan, de lo que me reconocí culpable involuntario, ${ }^{2}$ pero, salvo eso, apenas habían sufrido deterioro. Pedí quedarme con ellas y, dado que su destino era el fuego, me fueron concedidas sin dificultad como pago a mis servicios. Dos personas salieron de aquella casa más felices que cuando entraron; no sabría decir quién lo era más.

\section{FUENTE Y MÉTODO}

Como se ha puesto de relieve en diferentes trabajos de reflexión historiográfica, ${ }^{3}$ es todavía reciente el proceso de incorporación de esta fuente al campo de los estudios migratorios, especialmente en el caso de los gallegos, que sin embargo cuentan ya con destacadas aportaciones. ${ }^{4}$ Recibida con entusiasmo por los investigadores, la experiencia y el análisis crítico de sus características y contenido han provocado recientemente una progresiva actitud de prudencia hacia sus valores, cuyo resultado

${ }^{2}$ Coleccionista de sellos desde mi infancia, pude ver entonces la procedencia de algunos de los que guardo desde mi adolescencia y que obtuve de su propietaria a través de una intermediaria, buena amiga y conocedora de mis aficiones. Sin sospecharlo me había convertido en agente destructivo de documentación histórica y, pasados los años, podía comprobar, tal y como aseguraban los viejos moralistas, que en el pecado hallaba ahora también mi penitencia.

${ }^{3}$ X. M. Núñez Seixas, "Historiografía española reciente sobre migraciones ultramarinas: un balance y algunas perspectivas", Estudios Migratorios Latinoamericanos, 48 (2001), pp. 269-95 y "Otras miradas a la Historia de la emigración gallega: sobre cartas, memorias y fotos”, Estudios Migratorios Latinoamericanos, 58 (2005), pp. 483-503.

${ }^{4}$ Sin pretender ser exhaustivos, y a modo de referencia, sirvan de ejemplo los siguientes trabajos: R. Soutelo Vázquez, De América para a casa. Correspondencia familiar de emigrantes gallegos en Brasil, Venezuela e Uruguai: 1916-1969. Santiago de Compostela: Consello da Cultura Galega, 2001; id., "La correspondencia familiar de los emigrantes gallegos en América Latina durante el franquismo”, en A. Castillo y F. Montero (comps.), Franquismo y memoria popular. Escrituras, voces y representaciones. Madrid: Siete Mares, 2003, pp. 123-176; Emigración de retorno e dinámicas sociopoliticas locais na Galicia rural: unha microanálise dende Valga, 1890-1950. Santiago de Compostela: Concello de Valga, 2007; y X. M. Núñez Seixas y R. Soutelo Vázquez, As cartas do destino. Unha familia galega entre dous mundos, 1919-1971. Vigo: Galaxia, 2005. 
ha sido matizar buena parte de los desmedidos entusiasmos iniciales, como con acierto expone en su contribución el profesor Álvarez Gila. Ciertamente no carecen de fundamento sus observaciones, que en buena medida ponen de manifiesto lo que también ya señaló en alguna ocasión R. Soutelo: la carencia de un archivo bien constituido sobre el que trabajar. A diferencia de otros corpus documentales, contamos en este caso con materiales dispersos — social y geográficamente- y heterogéneos en su composición y contenido. Es verdad que disponemos de aportes de gran interés, pero sólo el paso del tiempo y el incremento de nuevas investigaciones irán permitiendo la acumulación de un sensible volumen de testimonios, tanto procedentes de origen como de destino, que nos posibilitará cruzar la información enriqueciendo así los análisis. Por otro lado, será necesario que los historiadores comiencen a valorar la importancia de complementar las epístolas con otras fuentes del entorno familiar, y no sólo las orales o fotográficas — metodología ya aplicada y que ha rendido excelentes resultados hasta la fecha-, 5 sino también las relativas al resto de la documentación conservada en el domicilio de los donantes (recibos de contribuciones, escrituras de compra venta, partijas...), lo que exigirá un largo y complejo proceso de concienciación que deberá convertirse en un objetivo más de la labor docente desarrollada en las aulas, única vía, como ya se ha demostrado, para abrir brecha en el sólido muro de la privacidad familiar, el gran obstáculo de este tipo de investigaciones. ${ }^{6}$

El proceso de clasificación de nuestros documentos fue complejo pues se trataba de muchas cartas, que tenían una cronología amplia además de una doble procedencia; la ciudad de Salvador de Bahía, en Brasil, y la capital de Argentina, Buenos Aires. La más antigua estaba fechada en 1919 y la postrera en el verano de 1977, pocos meses antes del fallecimiento de la destinataria, el último vástago familiar residente en la parroquia, que moriría en la primavera siguiente. Sumaban un total de 277 misivas, pero de composición muy heterogénea, repartiéndose de la siguiente manera: 166 de Brasil y 84 de Argentina. A éstas hay que sumar 27, que son borradores o primeras copias de la contestación de las destinatarias.

\footnotetext{
${ }^{5}$ Vid. por ejemplo el libro ya mencionado de Núñez Seixas y Soutelo, As cartas do destino.

${ }^{6}$ Algunas iniciativas hace ya tiempo que están en marcha, vid. al respecto R. Soutelo Vázquez, "Cómo recuperar las cartas familiares de los emigrados y qué hacer con ellas", en http://www.euskosare.org/komunitateak/ikertzaileak/ehmg/2/txostenak/como_recuperar_cartas_familiares (consultado el 23-07-2009).
} 
Todas constituyen un bloque homogéneo, salvo las dos más antiguas, datadas en 1919 y 1920, que tienen entidad propia y están desconectadas de las siguientes. El corpus brasileño se escalona entre 1934 y 1977, con una cesura importante a la altura de 1954, a la que nos referiremos más adelante, y que introduce un cambio sensible en su contenido. Las de Buenos Aires van desde 1937 hasta 1962. Finalmente, las respuestas de casa están fechadas entre 1939 y 1959, y no es una casualidad, pues se trata del periodo más intenso en el intercambio de misivas. Como hemos mencionado, suman en total 277, pero si les añadimos fragmentos con contenido significativo procedentes de los mencionados borradores o las tarjetas de felicitación navideña, superan holgadamente las 280.7

Estamos ante un conjunto documental que presenta unas características excepcionales. En primer lugar, porque se trata de un epistolario eminentemente femenino. En este caso, al contrario de lo que suele ser habitual, las mujeres no son meras comparsas sino las auténticas protagonistas. Son cartas escritas por mujeres y para mujeres, los hombres aparecen aquí de manera ocasional, tomando la pluma en nombre de aquéllas cuando están incapacitadas para hacerlo o para resolver asuntos de trascendencia — normalmente económicos- que entran directamente en ámbitos de su exclusiva competencia, pero realizada la tarea masculina, pronto vuelven a un segundo plano. ${ }^{8} \mathrm{Y}$ esto es importante porque marca con un sello particular el contenido de la correspondencia, que es eminentemente familiar, íntima; no es el mundo de los negocios, de las cadenas migratorias, de las inversiones económicas, de las reflexiones políticas, el que vemos aquí prioritariamente reflejado. Se trata sobre todo de una correspondencia del día a día, que muestra la crónica cotidiana de las comunidades situadas a ambas orillas del Atlántico; unas misivas, en suma, que nos permiten entrar en un nivel diferente en el que se advierte la presencia de forma más intensa de la esfera de lo doméstico, de aquello que empezaba cuando se cerraban las puertas del negocio.

\footnotetext{
7 Obviamente no son las únicas encontradas. Había también misivas de contenido oficial, así como otras escritas por algún vecino de la parroquia con quien mantenían lazos de amistad o interés. Éstas no van incluidas en el cómputo mencionado.

${ }^{8} \mathrm{Y}$ esto en el caso concreto de Brasil. En España las redactoras se mantuvieron viuda y solteras, por lo que ningún hombre intervino en su trayectoria vital. En Argentina también fue la hermana quien llevó el peso de la correspondencia, auxiliada de sus hijas en caso de necesidad.
} 
Otra particularidad la constituye el hecho de que contamos con respuestas. Normalmente los epistolarios estudiados hasta la fecha son unidireccionales; tenemos sólo una imagen, una voz, la que viene de América, nos falta la visión de acá. El que estudiamos no se aparta mucho de la norma, pero sí hay algunas aportaciones novedosas. Las residentes en Galicia sabían leer y escribir,'9 pero su instrucción en materia de escritura era muy deficiente, máxime cuando habían sido alfabetizadas en castellano siendo gallego hablantes, lo que introducía una nueva barrera para su capacidad de expresión. Por eso escribían borradores, a veces de la carta entera, a veces, lo habitual, sólo de los párrafos donde querían ser más claras y precisas. No son muchos, el papel y la tinta suponían un lujo, ${ }^{10}$ por eso estamos ante escritos intrincados, a veces auténticos palimpsestos en los que las líneas de diferentes escritos se solapan o se suceden sin solución de continuidad, en confusa mezcolanza, con listas de la compra, cuentas de la leche vendida en la taberna o las fechas en que las vacas fueron cubiertas por el semental. Pero son documentos de contenido precioso, espontáneos, directos, que nos hablan en primera persona de cómo se ven las cosas desde Galicia, de lo que preocupa, de lo que se siente, con el desgarro de quien no se ve constreñido por eufemismos producto de una educación y unas convenciones adquiridas en la nueva sociedad de la que se forma parte. Además tampoco sufren el filtrado que ejercen los hijos, cuando en determinados momentos actúan como amanuenses $^{11} \mathrm{o}$ cuando, fallecidos sus padres, se convierten en protagonistas, y cuya educación los integra en un universo mental completamente distinto al de sus

${ }^{9}$ La parroquia contó con un maestro desde 1857. Esto explica que incluso las dos mujeres de mayor edad pudieran ser autónomas a la hora de redactar sus textos.

10 En carta de diciembre de 1948, Emilia desde Brasil promete enviar en cuanto tenga portador el papel para correo aéreo que le pide su hermana desde España.

${ }^{11}$ Sólo Elvira en Buenos Aires necesitó recurrir a la escritura vicaria de su hija mayor en las primeras misivas enviadas. Emigrada muy joven, no llegó a tener el dominio de la escritura que demostraban sus hermanas. Las escasas líneas que incluye en alguna ocasión muestran su falta de habilidad en este terreno. Sin embargo más adelante mejoró ostensiblemente, hasta el punto de ser totalmente autónoma. Probablemente el proceso educativo de los hijos, como en otros casos, acabó influyendo positivamente en su propio nivel de instrucción. Vid. P. Cagiao Vila, "La experiencia argentina de las mujeres gallegas", en R. Farías (comp.), Buenos Aires gallega. Inmigración, pasado y presente. Buenos Aires: Gobierno de la Ciudad Autónoma de Buenos Aires, 2007, p. 165. El ascenso de nivel social que por matrimonio experimentó Emilia repercutió también en su formación intelectual, lo demuestra no sólo su mejoría respecto a la escritura que continúan empleando las que residen en Galicia, sino también las disculpas que pide en ocasiones a sus familiares -que escribían sensiblemente peor- por la mala letra que emplea. 
mayores, en especial de los que permanecen en el terruño natal, lo que contribuirá a abrir un amplio foso entre ellos.

\section{LAS TIERRAS Y LOS PROTAGONISTAS}

San Andrés de Anceu es una parroquia que forma parte del ayuntamiento de Ponte Caldelas, en la provincia de Pontevedra. Territorio afectado por un intenso proceso migratorio desde las últimas décadas del siglo XVII —orientado preferentemente hacia Portugal desde el final de la Guerra de Sucesión—, se integró con fuerza en el éxodo americano a partir del último tercio del Ochocientos, decantándose claramente sus vecinos por las tierras del Brasil, lo que no es extraño si consideramos su trayectoria anterior. ${ }^{12}$ Esto supuso una importante merma para la población del municipio, que pasó de 7356 habitantes en 1887 a los 6513 que figuran en el censo de 1930. Anceu refleja claramente esta tendencia, pues sus efectivos humanos en el mismo periodo oscilan desde los 513 a los 402 individuos, evolución que, a diferencia de lo que sucede en el conjunto del municipio, se alarga en el tiempo, de modo que el censo de 1960 sólo le asigna 348 almas. ${ }^{13}$

Como señalábamos unas líneas atrás, Brasil se convierte en el principal punto de destino de estos ausentes, fundamentalmente la ciudad de Salvador de Bahía, en el nordeste del país. Antigua capital de la colonia hasta 1763, en que fue sustituida por Río de Janeiro, era un importante foco de producción de azúcar (desde 1534), cacao (desde 1746) y tabaco (desde 1757), lo que explica el importante movimiento comercial de su puerto en relación con la metrópoli. Desde mediados del siglo XIX se inicia también una incipiente actividad industrial del sector textil algodonero, en parte ligada a las dos actividades anterior-

\footnotetext{
12 J. Fernandes Alves: "Peregrinos do traballo. Perspectivas sobre a emigración galega en Porto", Estudos Migratorios, 4 (1997), pp. 69-81, así como D. L. González Lopo, "Los movimientos migratorios en tierras del interior de la provincia de Pontevedra entre 1801 y 1950: características y puntos de destino", Semata. Ciencias Sociais e Humanidades, 11 (1999), pp. 269-98, e id., "Se se mandassem embora não haveria quem servisse... Os galegos em Portugal: um exemplo típico de mobilidade en época pre-indus-

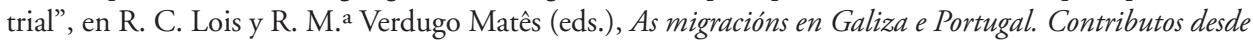
as Ciencias Sociais. A Coruña: Candeia, 2006, pp. 237-66.

${ }^{13}$ A. Pazos Labrador y X. M. Santos Solla, Poboación e Territorio. As parroquias galegas nos últimos cen anos. S. 1.: Difux, 1995, p. 362.
} 
mente citadas mediante la elaboración de sacos. ${ }^{14}$ Sin duda, el contacto de los naturales del territorio a que nos estamos refiriendo con Bahía viene de antiguo y debemos relacionarlo con la estrecha relación laboral que mantienen con Porto y, sobre todo, con Lisboa. Ya en las primeras décadas del Ochocientos consta la presencia de algunos pioneros en aquella tierra, fruto de las actividades comerciales o marineras que desarrollaban en la capital de la metrópoli. ${ }^{15}$ Sin embargo, hay que esperar a bien entrada la segunda mitad del siglo XIX para que se inicie un auténtico éxodo migratorio hacia esa ciudad. Según los libros consulares, las primeras altas de españoles residentes en la urbe son de la década de los sesenta, pero es a partir de 1883 cuando los registros portuarios nos informan de una llegada masiva, ${ }^{16} 17000$ individuos entre 1883 y 1950, siendo el periodo más intenso el que va de 1911 a 1940, con un total de 12014 entradas. ${ }^{17}$ De ellos, en torno a un 95 por ciento eran gallegos, de los que a su vez una proporción superior al 90 por ciento había nacido en la provincia de Pontevedra, y de estos

${ }^{14}$ En 1866 existían en Brasil nueve empresas que transformaban el algodón, cinco de las cuales estaban instaladas en Bahía. Vid. L. Pérez Leira, Galegos na Bahía de Todos os Santos. Vigo: Galicia en el Mundo, 2002, pp. 11-12, y J. M. Carvalhal Oliveira, "A cultura do fumo na Bahía: refletindo sobre a Convenção-Quadro”, Bahía Agricola, 7: 2 (2006), p. 57.

15 En 1805 se celebraron en San Finz de Forzáns (Ponte Caldelas) los funerales por Pedro Antonio Martínez, muerto en Bahía, "a donde fuera embarcado muchas veces". A lo mejor había coincidido en alguno de esos viajes con su paisano Juan Galvino, marinero que en 1804 llegó a Bahía, afincándose luego en la localidad costera de Belmonte. Román Núnez, "natural da Galiza" viajó desde Porto a Bahía en 1802. Cf. Arquivo Histórico Diocesano de Tui, Arquivo Parroquial de Forzáns, $2^{\circ}$ Libro de Difuntos, y Registro de Estrangeiros nas Capitanías 1777-1819. Río de Janeiro, 1963 (publicado por el Arquivo Nacional de Brasil bajo la responsabilidad de Guilherme Auler), pp. 18 y 46. Vid. D. L. González Lopo, "La presencia española en Brasil a principios del siglo XIX. Análisis crítico del Registro de estrangeiros nas Capitanías (1777-1819)", en M. a López Díaz (ed.), Estudios en homenaje al prof. José M. Pérez García. II. Historia y Modernidad. Vigo: Universidade de Vigo, 2009, pp. 160-62. Por su parte Jeferson Bacelar localizó en los archivos de Bahía algunos testamentos de gallegos datados en la segunda década del XIX, como el de Domingos Vázquez, "natural do Reino de Galiza, Bispado de Tui", redactado en 1817, y en el que declara, "tenho contas na cidade de Lisboa con António José de Lemos e outros aquí nesta cidade". Cf. J. Bacelar, Álbum de imigrantes galegos. Memoria visual da presença galega na Bahia. Salvador de Bahía: Universitária, 1997, p. 28.

${ }^{16}$ Es evidente, con todo, que a la altura de 1885 la presencia de gallegos en Bahía era ya muy significativa, en número y en poder económico, pues es en enero de aquel año cuando se constituye la Sociedad Española de Beneficencia, germen del conocido como Sanatorio Español, motivo de legítimo orgullo de la colectividad gallega hasta nuestros días. J. Bacelar, Galegos no paraíso racial. Salvador: Edufba, 1994, pp. 139-40.

${ }^{17}$ C. M. ${ }^{a}$ Leal Braga, Memórias de Imigrantes Galegos. Salvador de Bahía: Edufba, 1995, pp. 108-09. 
un 79 por ciento procedían de cuatro ayuntamientos limítrofes: Ponte Caldelas, A Lama, Fornelos de Montes y Pazos de Borbén. ${ }^{18}$ Ello, unido al hecho de que se trata de una comunidad proporcionalmente pequeña en el conjunto de la sociedad bahiana — menos de un 1 por ciento del total—, proporcionará una gran homogeneidad y cohesión a la que gustará de llamarse a sí misma colonia española o simplemente la colonia, que pronto comenzará a crear asociaciones de todo tipo — culturales, deportivas y de beneficencia- que contribuyeron a mantener la identidad del grupo hasta la actualidad.

La emigración a Argentina constituyó el destino mayoritario de la emigración gallega desde principios del siglo XX, recibiendo aquel país entre 1912-1918 al 56,5 por ciento de los que parten hacia el Nuevo Mundo y al 52,9 por ciento entre 1919$-30 .{ }^{19}$ Una corriente migratoria a la que paulatinamente se fue incorporando la mujer, de modo que si sólo el 14,75 por ciento de los que embarcaron en 1882 en puertos gallegos eran mujeres, en 1926 el porcentaje había aumentado al 45,11 por ciento. De los 949596 españoles que arriban a Buenos Aires entre 1882-1926, un tercio eran mujeres. ${ }^{20} \mathrm{Si}$ la emigración hacia Brasil había tenido en la parroquia de Anceu un fuerte componente masculino, la de Buenos Aires lo tendrá femenino, pues la oferta laboral en ambos destinos no era análoga para ambos sexos. Bahía será, económicamente hablando, un mundo de hombres y para hombres; allí el papel de la mujer quedará reducido durante mucho tiempo al de esposa o hija. La mujer que

${ }^{18} \mathrm{El} 21$ por ciento restante era oriundo mayoritariamente de aquellos municipios que con anterioridad a 1850 se habían caracterizado por tener una fuerte emigración a Portugal: Mondariz, A Cañiza, Redondela, Ponteareas, Salvaterra de Miño, Arbo, Crecente, etc. Vid. Bacelar, Galegos, pp. 45-46, y Braga, Memórias, p. 120.

${ }^{19}$ A. Vázquez González, "La emigración gallega. Migrantes, transporte y remesas", en N. Sánchez Albornoz (comp.), Españoles hacia América. La emigración en masa, 1880-1930. Madrid: Alianza, 1988, p. 87.

${ }^{20}$ A. Eiras Roel, "La emigración gallega a América en los siglos XIX-XX. Nueva panorámica revisada”, en id. (ed.): Aportaciones al estudio de la emigración gallega. Un enfoque comarcal. Santiago de Compostela: Xunta de Galicia, 1992, p. 191; B. Sánchez Alonso, La inmigración española en Argentina. Siglos XIX y XX. Colombres: Archivo de Indianos, 1992, pp. 82-83; M. ${ }^{a}$ X. Rodríguez Galdo et al., "Mulleres e emigración na historia contemporánea de Galicia, 1880-1930”, Estudos Migratorios, 6 (1998), pp. 27 y ss.; M. ${ }^{\text {a }}$ X. Rodríguez Galdo y X. Cordeiro Torrón, "Emigración y mercado de trabajo. Españoles en Argentina (1882-1926)", Revista Galega de Economía, núm. extraord. (2007), pp. 11 y ss.; P. Cagiao Vila, "Género y emigración: las mujeres inmigrantes gallegas en la Argentina”, en X. M. Núñez Seixas (ed.), La Galicia Austral. La inmigración gallega en la Argentina. Buenos Aires: Biblos, 2001, pp. 109-21; de la misma autora, "Mujer y emigración en la historia contemporánea de Galicia: el caso americano (Cuba y el Río de la Plata)”, en J. Hernández Borge y D. L. González Lopo (eds.), Mujer y emigración. Una perspectiva plural. Santiago de Compostela: USC, 2008, pp. 231-33. 
deseaba emigrar con fines laborales tendrá que orientar su rumbo hacia el Río de la Plata. En las cartas que llegan desde Buenos Aires se mencionan un total de seis mujeres naturales de Anceu allí residentes, ${ }^{21}$ y por un comentario realizado en 1948 sabemos que otra de las hermanas en algún momento de su vida se planteó también seguir los pasos de la mayor, aunque finalmente optaría por permanecer en el domicilio familiar seguramente por el convencimiento de que las cargas que lo gravaban, tanto presentes — cuidado de la hacienda — como futuras — atención a dos ancianas-, eran excesivas para una sola persona.

La familia objeto de nuestro estudio tiene una larga vinculación con la diáspora migratoria. El bisabuelo $(\dagger 1856)$ y el abuelo $(\dagger 1918)$ paternos de las protagonistas habían estado ausentes en Lisboa ya desde antes de contraer matrimonio y continuaron realizando desplazamientos cíclicos a dicha capital durante el resto de su vida laboral activa. Allí moriría también su abuelo materno en 1886 y, con toda probabilidad, su padre comenzó sus primeras experiencias migratorias a la orilla del Tajo acompañando a su progenitor, como era costumbre, desde tierna edad, pues al casarse con 23 años tuvo que presentar certificado de soltería, requisito preceptivo para todos aquellos que habían estado ausentes de su feligresía natal antes de contraer matrimonio. Sin embargo, más adelante cambió su destino migratorio dirigiéndose a Brasil, tal vez animado por el ejemplo de su cuñado, uno de los primeros vecinos de la feligresía en decantarse por ese destino rompiendo con la secular ligazón con tierras lusas. Allí llegaría a estar acompañado por su familia durante algún tiempo, ya que su segunda hija, Lindaura, nació y fue bautizada en la ciudad de Bahía. Con todo, su esposa e hijas acabaron regresando a Anceu, donde once años más tarde vendrían al mundo sus dos últimos vástagos, Emilia y Lealdina, las gemelas que animaron buena parte de la correspondencia objeto de nuestro estudio. Él retornó a Salvador, donde fallecería en 1919. Precisamente la carta que marca el inicio del epistolario, datada a principios de abril de aquel año, es la misiva en la que su hermano, también radicado en aquella ciudad, da cuenta a su cuñada del fallecimiento de su esposo con el tono crudo y descarnado de quien no sabe de literaturas ni acostumbra a andarse con rodeos: "querida cunhada y sobrinas, bos doi la triste noticia que tu esposo es muerto en el día 27 de Marzo y se enterró en el 28 del mismo".

${ }^{21}$ Una que llegó probablemente antes que las demás; cuatro que debieron arribar al mismo tiempo que nuestra protagonista o en momentos inmediatos, y dos más que se incorporarían en 1951; una hermana de las anteriores y otra acompañando a su esposo, natural de otra parroquia. 
Cuanto acabamos de decir nos explica por qué estamos ante un colectivo femenino, una madre y cuatro hijas, con la que conviven tres al enviudar, ${ }^{22}$ una de diecinueve y dos de ocho. A ellas hay que agregar a una cuarta mujer, hermana de la madre, que permaneció soltera toda su vida, y que si bien tenía y vivía en casa propia, siempre estuvo muy integrada en el grupo familiar de su hermana y sobrinas, que acabarían cuidándola en su vejez y heredando sus bienes.

\section{EL RITMO DE LA CORRESPONDENCIA}

Obviamente esas 277 misivas a que hacíamos alusión constituyen tan sólo una parte - sin duda significativa, como veremos - de las que en barco primero, más tarde en avión, cruzaron el Atlántico. Hemos hecho un intento de reconstrucción del volumen de la correspondencia intercambiada entre las protagonistas de nuestro estudio aprovechando las frecuentes referencias que en sus cartas hacen a las recibidas antes de contestar, información a veces tan precisa que nos permite calcular incluso el tiempo de tardanza en la recepción de la epístola desde origen a destino. ${ }^{23}$ Es evidente que nunca llegaremos a conocer el número total de cartas, por cuanto algunas se perdieron en el correo — algo a lo que también aluden sus redactoras- y otras no se han conservado. El total de misivas de cuya existencia tenemos constancia se distribuye de la siguiente manera:

\begin{tabular}{lcccc} 
Destino correspondencia & 1934-Julio 1954 & Agosto1954-1963 & 1964-1977 & Total \\
\hline De Bahía a Anceu & 128 & 37 & 4 & 169 \\
De Anceu a Bahía & 102 & 22 & 4 & 128 \\
De Buenos Aires a Anceu & 48 & 37 & - & 85 \\
De Anceu a Buenos Aires & 27 & 22 & - & 49 \\
De Bahía a Buenos Aires & 12 & 14 & - & 26 \\
De Buenos Aires a Bahía & 23 & 15 & 1 & 39 \\
Total & 340 & 147 & 9 & 496 \\
\hline
\end{tabular}

${ }^{22}$ La hermana, mayor, Elvira, ya residía en Buenos Aires al morir su padre, probablemente desde hacía un par de años.

${ }^{23}$ A veces se apuntaba este dato en el sobre, como en uno de 1939 donde consta "recibimos aquí el 9 febrero con fecha 2 de Enero". 
El cuadro nos ofrece una información muy significativa que conviene analizar detenidamente. Los cortes que hemos establecido en julio de 1954 y diciembre de 1963 coinciden con acontecimientos de gran relevancia y que van a incidir significativamente sobre la correspondencia. El primero es el fallecimiento de la hermana residente en Brasil; el segundo el de su gemela en Anceu, seguido muy poco después por el de la hermana de Buenos Aires, lo que provoca una ostensible caída en el intercambio de misivas. A la muerte de Emilia, viuda desde 1948, sus hijos tenían 19, 17, 16, 14 y 8 años; esto supuso un cambio radical en la estructura y la convivencia familiar, pues los dos mayores, varón y mujer, asumieron el papel de padres del resto de los hermanos. Adolescentes con una carga enorme sobre sus espaldas, apenas tenían tiempo para mantener el ritmo de escritura de su madre con unas tías, además, de quienes les separaba no sólo una gran distancia geográfica, sino también cultural. La muerte de Lealdina a finales de 1963 supuso la ralentización definitiva, si bien es probable que la caída no fuese tan brusca como el cuadro refleja, pues posiblemente, como atestigua el lugar y estado de las cartas que hemos encontrado de esta época, hubiese un menor cuidado en su conservación. En cualquier caso, los contactos y la relación de afecto no se interrumpieron, como demuestran los viajes de sobrinos a España en los años setenta y el hecho de que finalmente éstos acabaran heredando el patrimonio de sus tías; bien es verdad que, tal y como afirmaba Lealdina en carta de 9 de Agosto de 1959 a una prima, después de una larga queja por la supuesta indiferencia de los sobrinos ante su situación, "nós non temos máis ningén".

La relación con Buenos Aires fue muy diferente pues hubo siempre un mayor distanciamiento afectivo que no logran ocultar los convencionalismos de la literatura epistolar, y el volumen comparativo de la correspondencia así lo atestigua. Habiéndose marchado Elvira muy joven de casa y en unas circunstancias conflictivas, como relatará en una dura carta con la que sin duda se reinicia la relación tras un periodo prolongado de silencio, sus contactos fueron menos regulares excepto en el periodo 1949-1957. En efecto, aunque en ocasiones se manifieste su claro deseo de ser aceptada sin reticencias por su madre y hermanas, nunca llega a desaparecer esa invisible barrera basada en antiguos resentimientos y consolidada por una vida labrada con esfuerzo y al margen del amparo familiar. La muerte de Emilia cambió un poco las circunstancias, pero su rápido deterioro físico, producto de una diabetes muy avanzada combinada con 
una dolencia hepática, la obligaron a reducir su actividad epistolar desde principios de los sesenta. De hecho, en su última carta personal, fechada en mayo de 1962, anunciaba que en el futuro seguiría escribiendo su hija mayor, pero ya no se conservan más documentos de esta procedencia. Posiblemente su fallecimiento en los meses inmediatos o a principios del año siguiente interrumpió de modo definitivo el contacto, y no por casualidad, sino como resultado de la diferente actitud observada por las hermanas en la educación de sus retoños. Mientras Emilia desde Bahía acostumbró a sus hijos desde muy jóvenes a escribir directamente a su abuela y tías, Elvira desde Buenos Aires llevó siempre el peso de la correspondencia en la que nunca involucró personalmente a sus hijos, que sólo le sirvieron de amanuenses en momentos puntuales. Este mayor despego justifica la trayectoria posterior. Con Bahía las relaciones de Elvira mantienen un mayor equilibrio, pues su instinto maternal hacia unos sobrinos desamparados a edad tan tierna excitó su atención hacia ellos — les ofrecerá incluso acogerlos en Buenos Aires - e hizo que la correspondencia no sólo no decayese, sino que incluso es posible que se incrementara al entrar en ella los hijos más jóvenes, que tenían una edad similar a la de sus primos brasileños, si bien este flujo es más difícil de controlar al ser autónomo respecto al de su madre. De su permanencia en el tiempo da cuenta una carta dirigida a Lindaura desde Bahía por su sobrina mayor en diciembre de 1972, en la que incluye noticias de sus primos porteños.

Cuando se repasa el calendario de las misivas conservadas, lo primero que llama la atención es la intensidad de su frecuencia; estamos ante lo que podríamos denominar una escritura casi compulsiva. La media de cartas enviadas desde Brasil a Anceu entre 1934-1953 es de casi siete por año. Si dejamos fuera el período 1942-1945 en que la II Guerra Mundial repercutió negativamente sobre la circulación del correo, la media asciende a nueve, casi una carta por mes, una proporción que se ve superada en algunos años, como 1938, 1939 o 1949, en cada uno de los cuales viajaron desde Bahía trece cartas; en 1953 fueron doce, once en 1952 y diez en 1936. En sólo el mes de octubre de 1938 Emilia llegó a escribir un total de cuatro cartas, y tres en mayo de ese año, octubre del siguiente y mayo de 1940, pues escribía no sólo a su madre, sino también a su hermana - a pesar de residir ambas bajo el mismo techo y de contarles prácticamente lo mismo- y a su tía, y eso que en ocasiones se queja de que el 
mucho trabajo que le dan los niños — alumbra seis entre 1935 y 1946 - le resta tiempo para escribir y tiene que hacerlo a horas muy incómodas. ${ }^{24}$

Sin alcanzar semejante ritmo, también sorprende la frecuencia con que Elvira coge la pluma en Buenos Aires, en especial si consideramos las circunstancias que ya tuvimos ocasión de comentar. Es cierto que entre 1937-1953 —el mismo tramo cronológico atrás considerado- la media es mucho más baja, algo menos de tres cartas por año, ${ }^{25}$ pero entre 1949-1957 casi se triplica el volumen de correspondencia, alcanzando las siete, con puntas en 1953 y 1954 en los que deposita en el correo 12 y 10 cartas respectivamente, con la particularidad de que en este caso no existe más que un destinatario; la madre al principio, la hermana después. ${ }^{26}$ Obviamente el contenido de las cartas es muy breve y en apariencia casi intrascendente, algunas noticias de la situación familiar, besos y abrazos, lo que confirma que no sólo es la información remitida la que realmente importa, sino la carta en sí. Ella misma es la que tiene entidad; el verdadero mensaje no está escrito sólo en los renglones, sino en su materialidad, y su relevancia en el hecho de recibirla. Tal vez nadie como el director de cine gallego Chano Piñeiro en su cortometraje Mamasunción supo poner en imágenes este hecho, que tan bien se refleja en la cita con que abríamos nuestro trabajo y en los recuerdos de M. ${ }^{a}$ Rosa Iglesias:

También la espera y recepción de la correspondencia era un ritual ansioso que compartíamos. Las cartas venían por barco y demoraban un mes o dos. Si aparecía alguna boiña (polilla grande) revoloteando en casa, sabíamos que había carta de España en camino. Yo acechaba la llegada del cartero una o dos semanas, y luego ocurría el milagro. Yo la leía en voz alta porque éramos incapaces de soportar la espera del turno respectivo. Luego, a solas, la releía cien veces. ${ }^{27}$

${ }^{24}$ Después de justificar los borrones de una carta como resultado de la travesura del hijo mayor y la mala letra de otra por no poder perder de vista al tercero, pasan a ser frecuentes comentarios de este tenor: "desculpe mal escrita, la icen de noche" (sic) (1938); "está muy mal escrita que es de noche para sere mas istensa" (1940).

25 Entre 1937-1948 la media no alcanza a una por año.

${ }^{26}$ En concreto, la secuencia de las cartas en aquellos dos años es la siguiente: enero, febrero, marzo, abril (dos cartas), julio, agosto (dos cartas), octubre, noviembre, diciembre, enero, febrero, abril, agosto, septiembre (dos cartas), octubre, noviembre, diciembre y enero.

${ }^{27}$ M. ${ }^{a}$ R. Iglesias López, "Con las raíces al aire. La experiencia de los emigrantes gallegos a través de nueve protagonistas”, en R. Farías (comp.), Buenos Aires Gallega, pp. 177-78. 
Y todo esto nos explica las quejas continuas por la tardanza en recibir la correspondencia, quejas que pueden parecer exageradas si no las consideramos desde este punto de vista. Así, en carta de 19 de diciembre de 1938, Emilia se lamenta del mucho tiempo transcurrido sin noticias de casa; ese mucho tiempo es mes y medio. Si tenemos en cuenta que en esa época las sacas del correo se transportaban en barco y que el término medio empleado en su traslado se sitúa en los 36-38 días, podremos valorar con mayor precisión aquel reproche. A partir de la segunda mitad de 1940, según nos informa un comentario de Emilia, la correspondencia comienza a viajar en avión, lo que acortó los tiempos, pero aumentó las impaciencias. Entre 1947-1954 la media en la recepción del correo es de 10/18 días, pero si atendiéramos sólo a los comentarios que se continúan haciendo sin ocuparnos de medir los intervalos, parecería que no ha tenido lugar ningún cambio. ${ }^{28}$

Esta actitud nos enseña otra cosa, que la aparente intrascendencia de las cartas no era tal. De hecho, su contenido contribuyó a mantener íntegra la estructura familiar al ir informando de los cambios introducidos con el paso del tiempo (nacimientos, defunciones, bodas) e integrando en la dinámica familiar a las nuevas generaciones, que de esta manera, sin haberse conocido físicamente o sólo muy levemente, iban creando lazos afectivos y sentimientos de responsabilidad respecto al bienestar de los ausentes. ${ }^{29}$ Por eso los comentarios, en apariencia insignificantes, acerca de las travesuras de los niños que tenían lugar durante la redacción de la carta, ${ }^{30}$ enriquecían en la distancia la convivencia familiar, que se incrementaba con el envío regular de fotografías, ${ }^{31}$ de modo que esos, en apariencia, inconsistentes renglones, amarraban a los miembros del grupo con tan sólidas ligaduras, que sólo la muerte, y no la ausencia,

${ }^{28}$ El correo aéreo dio respuesta a una vieja reivindicación de la colonia residente en Bahía y de la que se hacía eco la prensa gallega en 1909. Las cartas llegadas de la Península sólo eran distribuidas después de su arribo a Río de Janeiro, a pesar de que los barcos hacían escala en el puerto de Salvador. Eso provocaba que se duplicase el plazo de espera de su recepción. Aunque una nota de la Dirección General de Correos de España con fecha de 27 de junio de 1910, dirigida al presidente de la Sociedad Española de Beneficencia, daba por solucionada esta anomalía, lo cierto es que, a tenor de la información procedente de nuestras epístolas, la situación no se regularizaría hasta tres décadas más tarde. Cf. Pérez Leira, Galegos, pp. 187-90.

${ }^{29}$ Esta circunstancia se aprecia bien en la correspondencia de la familia Naveiras, estudiada por Núñez Seixas y Soutelo (As cartas do destino, pp. 197 y ss.), de manera especial entre Vicente y su sobrino Juan Armando.

${ }^{30}$ La aparición de borrones en una carta ("son traballos de Manoliño") o, por ejemplo, lo apresurado de la redacción porque no puede perder de vista a otro, ya que "es un peligro".

31 Así comentaba la abuela en Marzo de 1951 la recepción de una foto de sus nietos de Brasil: "meus filliños quedei mui contente por ver cuatro caraveles tan vonitos". 
conseguirá desatarlos. La trayectoria afectiva de los hijos de Emilia, que aún no nacieran cuando se inicia el intercambio epistolar, y la devoción inquebrantable que les guardan su abuela y tías, a pesar de los contratiempos, así lo demuestra.

\section{LOS ENVÍOS DE ALLÁ...}

En los trabajos publicados hasta la fecha, sus autores han puesto de manifiesto el hecho de que los emigrados mantienen durante mucho tiempo un sentimiento de responsabilidad hacia los que se quedan. Sienten que es su obligación atender a su subsistencia con el fruto de su trabajo enviándoles el dinero necesario, primero para desempeñarse por el costo del propio viaje en muchos casos, y luego haciéndoles llegar el complemento con que atender a aquellas necesidades que era incapaz de cubrir la agricultura de subsistencia que practicaban. Con todo, es ésta una cuestión difícil de estudiar por el carácter opaco de los archivos de las entidades bancarias, ${ }^{32}$ así como por el frecuente empleo de vías informales para hacer llegar estos envíos, ${ }^{33}$ en especial en aquellos momentos en que la evolución negativa de la economía en los países americanos provocaba la promulgación de leyes restrictivas a la exportación de capital. Sin poder calcular de forma exhaustiva los montos, la correspondencia nos informa de lo habitual que era recurrir a estos mecanismos privados para evitar el control fiscal, así como el recurso a la entrega de cantidades procedentes de cuentas abiertas por los emigrados en entidades bancarias del solar natal, cuya red se expandió notablemente gracias a estas remesas. ${ }^{34}$

Leyendo las cartas que nos ocupan se obtiene la idea de que salvo en momentos puntuales —el período 1942-1946—, ${ }^{35}$ los viajes entre los dos continentes

${ }^{32}$ R. Villares Paz, "El Indiano gallego. Mito y realidad de sus remesas de dinero”, en Indianos. Monografias de los Cuadernos del Norte, 1984, pp. 29-34

${ }^{33}$ R. Soutelo Vázquez, "Proyectos migratorios, itinerarios laborales y redes microsociales de los emigrantes en su correspondencia familiar: dos gallegos en Buenos Aires (1950-1966)", Migraciones y Exilios, 7 (2006), pp. 127.

${ }^{34}$ J. de Juana y X. Prada, Galicia Contemporánea. A Coruña: Vía Láctea, 1996, pp. 90-91.

35 A finales de enero de 1942, después de un acercamiento diplomático a Estados Unidos, Brasil rompe relaciones con el Eje. Entre febrero y agosto de 1942 la marina alemana atacó a veintiún mercantes brasileños en las costas del país, lo que llevó al gobierno a declarar la guerra a Italia y a Alemania. Desde agosto de 1944 una fuerza expedicionaria brasileña intervino en la campaña de Italia. Vid. B. Bennassar y R. Marin, História do Brasil. Lisboa: Teorema, 2000, pp. 348-49. 
fueron lo suficientemente fluidos como para garantizar un contacto permanente. Emilia e hijos, en sus cartas desde Bahía, mencionan los siguientes desplazamientos de parientes, amigos y vecinos, tanto de la propia parroquia como de las inmediatas:

\begin{tabular}{lccc} 
Períodos & Idas a Galicia & Regresos de Galicia & Total \\
\hline $1935-1940$ & 16 & 13 & 29 \\
$1941-1946$ & - & 3 & 3 \\
$1947-1953$ & 25 & 13 & 38 \\
$1954-1960$ & 5 & 7 & 12 \\
Total & 46 & 36 & 82 \\
\hline
\end{tabular}

Ciertamente no se trata de una relación exhaustiva, pero sí nos ayuda a entender que los contactos entre ambas orillas del Atlántico, y no sólo por carta, eran más habituales de lo que cabría pensar. Además, es necesario explicar que la evolución del número de viajes no refleja su volumen total, sino, salvo momentos coyunturales ya indicados, el interés por encontrar portadores para sus envíos, que claramente disminuye a partir de la muerte de Emilia. Por otro lado, el aumento de la presión aduanera fue haciendo surgir un sentimiento de rechazo hacia los paquetes foráneos, que amenazaban con aumentar en exceso el propio equipaje. Así pasamos de un periodo de total disponibilidad, en que incluso se mandaban baúles propios en medio del equipaje de quien viajaba, a periodos en que deberán conformarse los solicitantes con un simple paquete, ${ }^{36}$ cuyo volumen irá también disminuyendo con el paso del tiempo, sobre todo en relación a aquellas personas $-\mathrm{y}$ nuestros protagonistas entran en esta categoría-, con las que no existía un sentimiento de gratitud y obligación de reciprocidad al no llevar a cabo viajes en los que pudieran retribuir el favor recibido. Se comprenden así comentarios como el escrito por Lealdina en un trozo de papel sin fecha: "es pouco que no quería llevar, queríamos

${ }^{36}$ En abril de 1949 recomendaba Emilia a sus hermanas que no diesen publicidad entre sus vecinos a lo recibido ("boca calada no entra mosca nela"), pues el portador rechazara otras solicitudes, lo que diera lugar a enfados. En febrero de 1951 le tocó a ella sufrir esta situación ("mandaron una mala sin decir nada"), y en carta de marzo de 1952 justificaba la escasa cuantía de lo enviado diciendo que cuando alguien partía, todos querían mandar. 
mandar más [pero] el no queria llevar nada, le pedimos por el alma de su madre, él nos digo, siendo un paquetiño mui pequeño, así que es poco"; o el exabrupto de Lealdina en una carta a su sobrina en Noviembre de 1955 después de haber recibido una negativa rotunda de un posible portador: "para esa maldita terra non ai quen leve nada”.

En las cartas de Brasil constan varios envíos, siempre por manos de particulares, por valor de 3400 pesetas entre 1936-1952, además de otros varios sin especificar cuantía. Sin embargo, las remesas más sustanciosas las recibieron a partir de 1943 de una renta fijada sobre depósitos bancarios existentes en Galicia, momento en que, como se explica, "de aquí no se puede enviar nada". ${ }^{37} \mathrm{La}$ cantidad fijada, 600 pesetas al año, la recibieron de modo regular convirtiéndose desde 1952 — con problemas a los que luego nos referiremos - en la única remesa que perciben los familiares residentes en Galicia. Por aquel entonces la coyuntura económica de Brasil comienza un periodo crítico que tendrá graves repercusiones sobre los envíos en numerario. Desde enero de 1952 comienzan a aparecer en las cartas de Brasil comentarios relativos a la carestía de la vida y al poco rendimiento que se obtiene del dinero depositado en el banco, comentarios que van acompañados de reflexiones acerca de una situación nunca experimentada antes. En enero de 1953 Emilia hace referencia al ascenso imparable de la inflación:

Según me dices la vida está megor [ahí] que aquí. Agora aquí está como el tiempo de la guerra ai. Cuesta una galinha 40 pesetas, carne de 18 e 20 pesetas, aceite de 40 e 50, café 27 , açucar 5 , ovos 10,15 .

Por otra parte, el cruceiro se devaluó en casi un 60 por ciento entre octubre de 1953 y diciembre de $1954 .{ }^{38}$ Esto trajo consigo nuevas estrategias por parte de la colonia gallega, que decidió invertir en el sector inmobiliario. Emilia, siguiendo el ejemplo de tres personas de su entorno, decidió comprar un terreno y construir apartamentos. Así se lo comunica a su hermana en enero de 1952, motivo que ale-

\footnotetext{
37 Véase la distribución de estas remesas en el Apéndice.

38 Sobre la evolución de la economía brasileña en este periodo pueden consultarse, E. A. Vieira, Estado e miseria social no Brasil. De Getúlio a Geisel (1951-1978). São Paulo: Cortez Ed., 1985, pp. 35-36, 94-95 y 160; C. Prado Júnior, História Econômica do Brasil. São Paulo: Ed. Brasiliense, 1997, pp. 303 y ss.
} 
gará en el futuro para justificar la disminución sustancial primero y, más tarde, la interrupción de los envíos en metálico. ${ }^{39}$ Su fallecimiento en el verano de 1954 provocó un cambio importante en las relaciones con Galicia. La situación económica en casa después de un periodo favorable, que incluso había permitido acometer algunas obras de mejora en la vivienda familiar, ${ }^{40}$ gracias sin duda a las ayudas económicas recibidas, inició una etapa negativa agravada por los gastos de diversas enfermedades que se irán prolongando en el tiempo. ${ }^{41}$ Por otra parte, la renta vitalicia establecida en 1943 empezó a cobrarse mal desde principios de 1950 por problemas que nunca llegan a concretarse bien, pero que tienen su origen en dificultades que les pone el responsable del banco para efectuar el pago. Todavía siete años más tarde, el sobrino mayor se veía obligado a escribir una carta poniendo las cosas claras, en medio de una creciente indignación hacia el personal de la entidad, tras cuya actitud sospechaba una malversación en beneficio propio. De todas formas en aquel momento, incluso aquella renta, inalterable desde sus orígenes, se había depreciado lo suficiente como para significar muy poco en los menguados ingresos de las tías de Galicia, cuyos gastos, a tenor de sus misivas, se disparaban. ${ }^{42}$ Sin embargo la situación en Brasil, lejos de enderezarse, continuaba precipitándose en un negro pozo. Una prima se lo decía con toda claridad en diciembre de 1959: "La situación aquí está horrible". Este tipo de comentarios y las alusiones a la depreciación del cruceiro son constantes entre 1961-1964. No eran exageraciones. El índice de inflación había pasado de 100 en 1953 a 559 en 1961; 848 en 1962; 1473 en 1963 y 2811 en 1964 (llegaría en 1968 al 9767).43 Precisamente en enero de 1963 escribía el sobrino mayor a Lealdina:

${ }^{39}$ Desde enero de 1952 el gobierno brasileño limita la repatriación de beneficios del capital extranjero, medidas que se piensa en reforzar en 1954 para evitar la evasión de capitales. Vid. Bennassar y Marin, História, pp. 371-72.

${ }^{40}$ Añadirle un desván a la casa mediante la construcción de un cielo raso que ocultó las tejas (verano de 1936); instalación de luz eléctrica (otoño de 1937) y reforma general de la vivienda (verano de 1950). Innovaciones acogidas con júbilo por Emilia, que apostilla al saber de la última, "ya debieron hacerla hace tres años".

${ }^{41}$ En el borrador de una de sus cartas a Buenos Aires, escribe Lealdina en 1952, "aquí ai de todo, falta a peseta".

42 En diciembre de 1959 insistía Lealdina en carta a su hermana Elvira: "saberás que por aquí ay todo abendo cartos, sabes que aquí se jasta y no se jana, así como yo gastey muchos miles de pesetas. Dios le dea salud y suerte a nuestra prima, que tendo consideración do que yo llevo gastado me mandó 500 pesetas".

43 Prado Júnior, História, p. 319. El coste de la vida en Río de Janeiro se incrementó en 1961 en un 33 por ciento, en 1962 en un 51,6 por ciento y en 1963 en un 70,4 por ciento. Vid. Vieira, Estado, p. 160. 
[...] sei que o sufrimento para ai debe ser tan grande, e vontade de ajuda-las não falta, o que se passa é que a coisa por aquí vai de mal a peor e nós tamem somos sozinhos, e alem disso temos nossas irmãs [...] e o custo da vida nos leva tudo.

A nós se o cambio estíbese mais baixo seria muito mais interessante, pois poderiamos mandar sempre mais alguma coisa, entretanto a peseta está a 14,00 cruceiros, então 1.000 pesetas seriam 14.000 cruceiros.

Este párrafo describe muy bien la situación dramática que comienza a vivirse desde finales de los cincuenta y a lo largo de la década siguiente entre unos familiares en Galicia que siguen considerando a Brasil como tierra de promisión productora de riquezas y unos brasileiros cada vez más depauperados en sus economías e incapaces de representar el papel que habían desempeñado sus mayores. El inicio del milagro brasileiro a partir de finales de 1969 coincidiendo con la presidencia de Costa e Silva, aunque efímero, ${ }^{44}$ explica el reinicio de los envíos, que se apuntan en carta de 1973.

La situación en Argentina discurrió por un camino semejante. Elvira había vivido en unas condiciones muy diferentes, tanto en lo económico como en lo social. Mientras en Bahía el colectivo gallego era muy homogéneo y los naturales de la parroquia seguían constituyendo un grupo compacto, ella, casada además con un italoargentino, se encontraba aislada en Buenos Aires. Los contactos con sus paisanos son escasos y por eso no deja de referirlos a sus hermanas como algo extraordinario. Contamos con un buen ejemplo en la carta del 30 de noviembre de 1956, donde relata la reunión casual de varios de ellos en su domicilio, episodio que recuerda a uno de esos momentos especiales, casi mágicos, que experimentan a veces los emigrantes y que aparece tan bien descrito en algunas de las narraciones del escritor portugués de origen gallego José Miguéis. ${ }^{45}$ Esta circunstancia limitó mucho sus posibilidades de envío de numerario a casa, pues a pesar de los problemas que ya hemos relatado - y según recuerda a su madre en una de sus cartas-, hasta que no se vio muy cargada de familia (también tendrá seis hijos), "siempre le mandé [dinero] como una hija verdadera", 46 pero, carente de portadores, se vio obligada a utilizar los cauces financieros ofi-

\footnotetext{
${ }^{44}$ Bennassar y Marin, História, pp. 413 y ss.

45 J. Rodrigues Miguéis, Gente da terceira classe. Lisboa: Estampa, 1994, pp. 53-64.

${ }^{46}$ En esta misma carta asegura, "que si tiene casa es porque su hija supo andar en el mundo".
} 
ciales, lo que a la larga limitaría su capacidad de actuación. Con todo, la bonanza económica de los primeros años del peronismo facilitó sin duda el envío de remesas, ${ }^{47}$ a las que alude en sus misivas. Precisamente las medidas sociales aprobadas por el nuevo gobierno, como la extensión del sistema de pensiones a partir de 1946, le permitió a Elvira iniciar en 1949 los trámites para obtener su jubilación, prometiendo a su madre repetidamente que a partir de su cobro podría ayudarla mejor en el plano económico. Sin embargo, 1949 marca también un punto de inflexión en la economía argentina con el inicio de un importante déficit para el país y el comienzo de una espiral inflacionista durante los primeros cincuenta, que provocó la adopción de medidas como la prohibición de enviar dinero al exterior. ${ }^{48}$ Eso explica el comentario que figura en la carta fechada el 28 de noviembre de aquel año, en que Elvira muestra su preocupación por un envío que teme no hubieran recibido en casa, "porque dicen que no se puede mandar plata al extranjero".

No obstante las cosas cambian desde la primavera de 1952 gracias a la confluencia de dos factores. Por un lado, la puesta en marcha de una política de ajuste y austeridad económica con congelación de precios y salarios, que provocó la caída de la inflación; y por otro, la entrada como camareros en los trasatlánticos ingleses que viajaban a Buenos Aires haciendo escala en Vigo y Lisboa, de un pariente y un vecino. Esto permitió intensificar de modo directo los contactos con la casa materna y las remesas de dinero, que se mencionan en 1953, 1954, 1955 y 1957, en cantidades no siempre conocidas, aunque pequeñas, y que desde la última fecha no vuelven a citarse coincidiendo con la fuerte recesión económica que desde entonces experimenta Argentina, pues, en efecto, en 1959 los precios aumentaban un 127 por ciento mientras los salarios caían un 30 por ciento. ${ }^{49}$ La tibia recuperación de 1960-61 —la inflación desciende al 9,5 por ciento- explica el último envío conocido, 1000 pesos equivalentes a 607 pesetas, que iban acompañados de una última tentativa para convencer a sus hermanas, ya sin mayores a su cargo, para que dejasen todo y

${ }^{47}$ Entre 1946 y comienzos de 1949 el salario real aumentó en Argentina un 40 por ciento. J. Lynch et al., Historia de la Argentina. Barcelona: Crítica, 2001, p. 228.

48 Sobre la evolución de la economía argentina, vid. Lynch et al., Historia, pp. 192-217; 227-28 y 234 y ss.; A. Tello, Historia breve de la Argentina. Madrid: Sílex, 2006, pp. 186-88, y A. Ferrer, La economía argentina. Desde sus orígenes hasta principios del siglo XXI. Buenos Aires: FCE, 2008, pp. 282 y ss.

${ }^{49}$ Lynch et al., Historia, p. 250. 
viniesen a Buenos Aires a vivir en su compañía. ${ }^{50}$ Sin embargo, su edad — 60 y 50 años - la enfermedad de la más joven y sin duda el miedo a abandonar una rutina, dura, pero familiar y controlada frente a un mundo tan desconocido en que no había "canastro de millo, y molinos para moler la harina y horno para cocinar pan, ni chancho para matar, ni tocinera para cortar tocino, ni porotos, ni trigo, ni patacas...", como les decía Elvira en una de sus primeras cartas, fechada en febrero de 1938, debió pesar fuerte en su ánimo a la hora de convencerlas de que para ellas ya había pasado el tiempo de quemar las naves y empezar de cero.

Es difícil valorar el impacto real que estos envíos de dinero tuvieron sobre la economía familiar de Anceu. Sin duda durante mucho tiempo fueron vitales, pues proporcionaron un ingreso en metálico complementario, que en el caso del procedente de Brasil era regular y fijo, pues salvo la venta de leche - y su importe en buena medida servía para cubrir los gastos realizados a cuenta en la propia taberna donde la vendían- ${ }^{51} \mathrm{o}$ de algún ternero, carecían de otras fuentes de ingreso en metálico. Además, tal y como se hacía eco el periódico Faro de Vigo en febrero de 1948, los únicos precios que bajaban eran precisamente los de productos agrícolas y ganaderos como consecuencia de las importaciones de grano y carne procedentes de Argentina. ${ }^{52}$

Conocemos bastante bien algunos aspectos básicos de la evolución de la economía familiar gracias a los recibos que acreditaban el pago de las diferentes contribuciones, guardados tan cuidadosamente como la correspondencia en el ya varias veces mencionado baúl del desván. Éstos nos informan cómo desde la guerra civil hasta los años sesenta, la fiscalidad se fue incrementando paulatinamente, tanto por la subida de los conceptos tradicionales ${ }^{53}$ como por la apari-

${ }^{50}$ Carta de 16 de noviembre de 1961: "Comprendo muy bien lo que es dejar lo más querido, lo más inolvidable, pero ustedes están ahí luchando y trabajando mucho, y para qué tanto si aquí tendrían una vida mejor $[\ldots]$ aquí no tendrían que trabajar $[\ldots]$ pueden averiguar escribiendo a [...]. Ellos han venido a mi casa a visitarme y saben muy bien mi situación y la de mis hijos casados [...]. Serán recibidas con el corazón y los brazos abiertos [...] no les faltaría nada, ni de comer, ni de vestir y calzar y ni tampoco para divertirse. Ustedes pensarán porque no nos manda más dinero o más ropa [...] se hace mucho más difícil mandarles que gozarlos aquí".

${ }^{51}$ En agosto de 1954 ingresaron por venta de leche 452,50 pesetas y pagaron una factura al tabernero de 451,55 .

52 A. Giráldez Lomba, Sobrevivir en los años del hambre en Vigo. Vigo: Instituto de Estudos Vigueses, 2002, p. 341.

53 La contribución territorial a nombre de la madre de nuestras protagonistas evolucionó así (en pesetas): $1938,48,16 ; 1942,77,05 ; 1943,119,42 ; 1947,203,61 ; 1953,304,54 ; 1958,274,80$ y 1965, 229,50. 
ción de nuevos arbitrios en los años cuarenta y cincuenta, fijados para contribuir al sostenimiento de municipios y diputaciones provinciales, ${ }^{54} \mathrm{o}$ de las nuevas instituciones propias del franquismo, como la Hermandad Sindical de Labradores y Ganaderos, creada en 1944 y de afiliación obligatoria. ${ }^{55}$ Una circunstancia que se veía empeorada por el hecho de que no sólo debían satisfacer cargas propias, sino las correspondientes a los bienes de otros familiares que también explotaban y que nunca llegan a unificar fiscalmente con los propios, con seguridad por falta de documentos que les permitieran regularizar legalmente su herencia (bienes del padre y del tío muertos en Brasil, así como de la tía, incapacitada mentalmente desde 1951, todos fallecidos sin testar). A estos se unen las cargas correspondientes a los bienes raíces de su cuñado — desde 1948 propiedad de sus sobrinos_-, con cuyo pago correspondían sin duda a las donaciones recibidas desde Brasil, pues en ninguna de las misivas, ni antes ni después de 1953, se alude a los gastos que estos pagos les ocasionan. ${ }^{56}$ Además, como las contribuciones se pagaban a partir de los datos que figuraban en el catastro, lejos de disminuir tendían a consolidarse con el paso del tiempo: todavía en 1965 seguían pagando la cuota sindical de su madre y su tía, fallecidas once y nueve años antes - 37,70 y 10,55 pesetas, respectivamente-, e incluso las de su padre — muerto en 1919, veinticinco años antes de la creación de aquel organismo- y de su tío José, fallecido también en Bahía en 1946, que incre-

${ }^{54}$ De manera especial a partir de la aprobación de la nueva Ley de Bases de Régimen Local a finales de 1953, que entre otros recursos estableció en beneficio de las Diputaciones Provinciales el arbitrio de Rodaje y Arrastre, que consistía en el pago anual de la matrícula para los carros de vacas, sin la que no podían circular. Este importaba 21 pesetas en 1953, cuando el litro de leche se pagaba a los productores a una con cincuenta, de tal manera que para abonar tal contribución era necesario vender 14 litros de leche. Esto suponía en febrero de aquel año para Lindaura y Lealdina la producción de algo más de tres días. Sobre la aprobación y contenido de esta ley, vid. ABC, 1.12.1953, pp. 22-26.

55 Lo más lamentable es que no parece haber jugado este organismo ningún papel especialmente favorable en beneficio del campesinado, pues ya en 1966 se denunciaba su inoperancia. En cualquier caso, ninguna de las funciones que figuran en una larga lista impresa en el reverso de los recibos nos consta que hubieran repercutido favorablemente en la vida de Lealdina y su familia. Vid. P. Gil García, Las Hermandades Sindicales de Labradores y Ganaderos (1944-1977). Historia, documentos y fuentes. Cuenca: UCLM, 2005, p. 33.

${ }^{56} \mathrm{Al}$ contrario; cuando a finales de 1946 necesitan leña de una robleda propiedad de su cuñado piden permiso antes de tomarla, que no sólo les es concedido liberalmente, sino que se les autoriza a utilizar los bienes como propios sin solicitar licencia previa. En 1964 los sobrinos ceden a Lindaura, por entonces la única superviviente, el producto de la venta de un terreno de su propiedad por el que se interesaba un vecino de la parroquia. 
mentaban en un total de nueve pesetas y seis céntimos su gasto fijo anual. A todo ello debemos sumar los efectos del redondeo, pues la inexistencia de monedas por valor inferior a los cinco céntimos provocaba un aumento de las cuotas al alza, que además no se aplicaban globalmente, lo que habría disminuido su efecto, sino por conceptos, y teniendo en cuenta que buena parte de las contribuciones se abonaban por trimestres o semestres, el pico final no era desdeñable si pensamos que en los cuarenta y los cincuenta las chicas y las perras estaban lejos de ser la mera anécdota monetaria en que se convertirían más adelante. Que uno de los gravámenes a pagar se denominara Plagas del Campo no deja de ser una triste ironía. ${ }^{57}$ Veamos algunos números a modo de referencia:

\begin{tabular}{lccc} 
Años & Gasto contribuciones & Idem taberna & Ingresos (leche) \\
\hline 1953 & 1063,27 & 52,5 & 1427,35 \\
1954 & 1042,06 & 476,55 & 3216,30 \\
\hline
\end{tabular}

Ciertamente manejamos cifras muy incompletas, pues desconocemos el impacto de otros gastos, como el de la luz o los realizados fuera del comercio local (por ejemplo la compra anual del cerdo para la matanza en la feria celebrada en la capital del ayuntamiento los 5 y 20 de cada mes), o los ingresos derivados de la venta de otros bienes (terneros de las vacas). En cualquier caso, el grueso de sus ingresos - siempre sometidos a una gran aleatoriedad, pues las vacas no dan leche de forma regular, ni el aprovechamiento es el mismo si el animal está criando o no un becerro- puede calificarse de precario e inseguro y cualquier imprevisto podía desequilibrarlo con rapidez, ${ }^{58}$ mientras que los gastos eran seguros y firmes. De ahí la importancia de las remesas en metálico que recibían; precisamente la angustia que se aprecia en las cartas de finales de los cincuenta y los primeros sesenta por la disminución y posterior ausencia de tales envíos, así como los encendidos agradecimientos ante la llegada de alguno,

\footnotetext{
${ }^{57}$ Este impuesto, creado en 1908, comenzó a cobrarse de forma general y sistemática a partir de 1926, en teoría para combatir las que pudieran presentarse, y no habiéndolas para crear un fondo previsor. $L a$ Semana Veterinaria, n. ${ }^{\circ} 486$ (18/IV/1926).

58 Así las cosas no es de extrañar el pesar con que comunican a su hermana Emilia, en agosto de 1951, "saves que nos tivemos una perda con una vaca, tivemos que [a] dar por cen pesos", desgracia seguida de otra similar poco después.
} 
demuestra hasta qué punto fueron importantes..$^{59} \mathrm{La}$ amargura de algunos comentarios a terceros o la petición de préstamos a gentes ajenas al entorno familiar al dejar de recibir remesas desde 1962 demuestran la dependencia que existía de ellos para su subsistencia.

Pero además las cartas que estamos manejando nos ayudan a valorar aspectos que otras fuentes silencian y que probablemente tuvieron una repercusión tanto o más positiva que los modestos envíos de numerario que hemos venido comentando. Nos referimos al despacho de ropa y alimentos. En una empobrecida España de posguerra, con racionamiento de productos básicos y control estatal sobre la cosecha producida, ${ }^{60}$ la recepción más o menos regular desde América de aquellos productos por los mismos canales privados que ya hemos mencionado tuvo que tener una repercusión muy favorable. ${ }^{61}$ En el caso que nos ocupa, su interrupción, que coincidió en el tiempo con la de los envíos de dinero, no fue menos sentida por las receptoras.

En este tipo de envíos podemos establecer dos épocas bien marcadas. Una que se extiende desde 1935 a 1939, en que predomina claramente la ropa de todo tipo; y una segunda, a partir de principios de 1940, en que priman las remesas de comestibles, sin duda porque el inicio de la carestía de posguerra convirtió a éstos en más necesarios.

A diferencia de las partidas en metálico conocemos con bastante exactitud su composición, pues tanto para controlar que el transportista no se quedase con parte del género - ejemplo claro de la ancestral desconfianza galaica-, como para facilitar luego el reparto en destino, las cartas solían incluir una relación pormenorizada de las prendas, bien incorporada al texto de la misiva, bien adjuntando lista aparte. Entre 1936 y 1940, años especialmente difíciles para la obtención de textiles, ${ }^{62}$ Emilia hace, al menos, ocho envíos de ropa, cuyo contenido conocemos con detalle en

\footnotetext{
59 Así agradece a una prima un envío de 500 pesetas en julio de 1959: "queremos agradecer o que nos mandastes en que [buen] tiempo, dios vos dea salud y suerte y que sea a primeira limosna que topedes no ceo".

${ }^{60}$ Desde mediados de 1943 se establecieron cupos de entrega forzosa de maíz, medida que coincidió, además, con un año de mala cosecha por culpa de la sequía. Cfr. X. González Leirós, "Expansión de la miseria y auxilios de Falange. Pontevedra, 1939-1945", Espacio Tiempo y Forma. Historia Contemporánea, 14 (2001), pp. 393-97. Entre los papeles del baúl también se conservan impresos para declarar la cosecha obtenida.

${ }^{61}$ Vid. al respecto Soutelo Vázquez, Emigración de retorno, pp. 590-91.

${ }^{62}$ Giráldez Lomba, Sobrevivir, p. 174.
} 
seis casos. ${ }^{63}$ En conjunto, ese ajuar a repartir entre su madre, su tía y sus dos hermanas estaba compuesto por las siguientes prendas:

Ropa interior: 30 camisas, 7 enaguas, ${ }^{64} 2$ combinaciones, 2 corpiños, 5 sujetadores y 6 bragas. Asimismo, 5 metros de franela para elaborar ropa interior para el invierno y cuatro metros y medio de tela para combinaciones.

Ropa de vestir: 9 faldas, 6 pares de medias, 2 velos para llevar a la iglesia, 5 piezas de tela de buena calidad para confeccionar vestidos (tres de ellas miden cuatro metros cada una), ${ }^{65}$ un corte de vestido para su madre, 3 retalhos de fazen$d a^{66}$ y 2 mandiles.

Ropa de cama: 9 sábanas, 11 fronhos (almohadas cuadradas), 4 traveseiros (almohadas rectangulares) y 2 juegos de cama completos.

Ropa de casa: 21 toalhas ${ }^{67}$ y 12 servilletas.

Otros: 3 sacos para llevar grano al molino y traer la harina, un saco pequeño y una bolsa (saqueta), así como 10 madejas y 5 carretes de hilo de varios colores.

Calzado: un par de zapatos, un par de botines y dos pares de zapatillas.

Estas ropas venían acompañadas también de telas de sacos, tanto de harina como de azúcar, productos de los que se hacía abundante gasto en los negocios de capital gallego, con los que se elaboraban prendas de vestir y de cama que se ajustaban bien a las duras condiciones de la vida campesina; ${ }^{68}$ y también de ropa usada, que permitían un ahorro de dinero que podía ser destinado a gastos más

63 En un caso se limita a decir que manda "una mala de ropa" (julio de 1939) y en otro que envía unas ropas hechas con sacos de madrasto (marzo de 1940). Es éste un término propio del vocabulario del Nordeste brasileño para referirse a los tejidos de algodón blanco y fino.

${ }^{64}$ Las enaguas, camisas y combinaciones las elaboraba la propia Emilia con tela de saco, por eso a veces se disculpa por enviar poco o nada, pues la avisaran tarde y no había tenido tiempo de terminar su labor.

65 En la carta que acompaña los tres cortes de tela de cuatro metros cada uno, fechada el uno de febrero de 1940, añade: "mamá llebaba de gusto que hiciesen los vestidos en una costureira que cosa bien por que es buena facenda". Es decir, buen género.

${ }^{66}$ Posiblemente retales para remiendos.

${ }^{67}$ El término, en portugués y en gallego, es equívoco pues se emplea tanto para toallas de baño como para manteles de mesa. En cuatro casos nos consta que se hace referencia a estos últimos, pero del resto no se hace aclaración alguna, que, por otra parte, ni remitentes ni receptores necesitaban.

${ }^{68}$ Y no sólo. La escasez de textiles llevó también a que en las ciudades españolas se utilizara tanto los sacos blancos de azúcar y harina, como los de arpillera, para fabricar ropa, lo que obligó a los almacenistas a asegurarlos con fuertes fianzas para garantizar su devolución. En 1941 en el entorno vigués había que dejar en depósito 7 pesetas por cada saco de arroz y 7,50 por los de azúcar y garbanzos, recuperables al ser devueltos por los minoristas. Giráldez Lomba, Sobrevivir, pp. 213 y 315-16. 
perentorios e inexcusables. De ahí que la petición que de estos artículos hacen en sus cartas sea una constante, incluso en momentos tardíos, cuando los peores tiempos de la posguerra comenzaban a quedar atrás, como sucede en 1952, 1955 y 1959 , empleando siempre los mismos argumentos. ${ }^{69}$

De Argentina también se enviaron algunos paquetes con ropa usada - "porque nueva no se puede mandar", como se explicaba en carta de septiembre de 1955-y algunos pares de zapatos en 1954, 1955 y 1959. No obstante, las circunstancias familiares frustraron en ocasiones los beneficios que habrían podido producir. ${ }^{70}$

A partir de 1940 priman comestibles en los envíos. El fin de la guerra había traído consigo una importante carestía de alimentos básicos, lo que obligó ya desde 1939 a poner en marcha un sistema de racionamiento, que poco a poco iría perfeccionándose, y que mantendría su vigencia hasta junio de 1952. De ahí la preocupación de los residentes en América — también en Portugal— por hacer llegar a sus familiares y amigos diversos productos, fundamentalmente arroz, café, azúcar y harina de trigo (farinha do reino)..$^{71}$ Probablemente, a pesar de que en las cartas no se hace alusión al tema, sin duda por temor a la censura postal, ${ }^{72}$ en Bahía eran conscientes de las dificultades de abastecimiento que de esos productos existían en Galicia, ${ }^{73}$ algunos muy habituales en la dieta cotidiana, como ocurre con el café, cuyo consumo debió introducirse tempranamente en la comarca que nos ocupa a través de su larga relación con Portugal y más tarde con Brasil. A ellos se sumaban latas de té, muy apreciadas en destino, no tanto por su uso alimenticio cuanto terapéutico, pues se utilizaban para

${ }^{69}$ Así se expresa Lealdina en una carta a su hermana de Buenos Aires en octubre de 1952: "dices que te mande pedir lo que quiera [...], según dice Florinda ai los comestibles están muy caros y tu se tienes rropas usadas la mandas, como tu saves aquí todo sirve, se concierta una con otra". Y en otra de diciembre de 1959: "le mandé pedir a nuestras sobrinas la ropa usada ou algún saco [...] aquí todo como ti saves sirve".

${ }^{70}$ En agosto de 1954 Elvira da cuenta a sus hermanas del envío de un paquete de ropa y tres pares de zapatos, pero que ahora sabe no podrán usar porque la acaban de informar del fallecimiento de su hermana en Brasil y tendrán que vestir de luto.

${ }^{71}$ Farinha do reino es expresión característica del Nordeste brasileño para referirse a la harina de trigo, que durante la época colonial se enviaba desde Portugal (el Reino), en contraposición a la harina de mandioca que elaboraban los indios.

72 En octubre de 1940 aún se estampaba en los sobres de la correspondencia el sello de la censura postal gubernativa.

${ }^{73}$ En carta de agosto de 1946 el marido de Emilia, en una de las contadas cartas que escribe, responde negativamente a una solicitud de su suegra para que vayan a dar una vuelta a Galicia y se justifica aludiendo a la tierna edad de los niños y a que "la situación ai no está muy buena". 
curar una serie de dolencias, estomacales y oftalmológicas, tanto de personas como de animales. ${ }^{74} \mathrm{~A}$ ellos deben unirse los paquetes de maicena, producto utilizado para la elaboración de papas, más agradables sin duda que las elaboradas con la harina del maíz propio, alimento que habitualmente servía de última colación antes de irse a la cama. Ocasionalmente se citan también algunas tabletas de chocolate. Entre 1947$-1952^{75}$ Emilia mandó a su casa no menos de 40 kilos de azúcar, 11 de café, 19 de arroz y 10 de harina de trigo. A eso hay que sumar 9 paquetes de maicena, 5 latas y 3 paquetes de té negro, 3 tabletas de chocolate y una lata de mermelada (sin duda de guayaba). Desde un punto de vista cuantitativo, esas cantidades repartidas a lo largo de cinco años pueden parecer menguadas, pero si las valoramos desde un punto de vista cualitativo - en un momento en que su distribución, cuando había aprovisionamiento, se hacía por gramos- ${ }^{76}$ y considerando que hablamos del envío de una sola persona y a una sola casa, si bien en ocasiones nos constan repartos a terceros, no es difícil imaginar lo favorable de su impacto. Sobre todo si pensamos — dejando ya de lado el duro régimen de racionamiento a que esos productos estuvieron sujetos- el alto precio que llegaron a alcanzar. ${ }^{77}$ Asimismo debemos valorar el hecho de que llegaban a una economía de subsistencia y extraordinariamente austera, que sin duda obraba maravillas en la administración de su uso.

A estos envíos deben unirse otros que entran en una categoría diferente, y que permitían una modesta ostentación en el adorno personal. Tener brasileiros en la familia

${ }^{74}$ Todavía hoy se mantiene la costumbre entre las personas de mayor edad, quienes siguen considerando como un obsequio precioso una lata de chá preto llegado de Brasil o Portugal. Véase al respecto la descripción de X. Castro, A lume manso. Estudios sobre historia social da alimentación en Galicia. Vigo: Galaxia, 1999, p. 130.

75 Entre 1940 y 1946, coincidiendo con la II Guerra Mundial, se produce una caída en la correspondencia y en los envíos que no es casual. De hecho, en carta de 29 de mayo de 1940 Emilia advierte a sus hermanas que no dejan embarcar nada "por estos meses", pero que confía será por poco tiempo. Sin embargo el 16 de enero de 1943 ordenan desde Bahía se les haga un pago de los fondos que tienen en España a modo de compensación "pues no se puede mandar nada".

${ }^{76}$ El libro de A. Giráldez es muy esclarecedor. En Vigo en febrero de 1940 el azúcar se repartía a razón de 250 gramos por persona, pero entre enero y abril de ese año sólo hubo tres repartos de azúcar y dos de arroz. Opus cit., p. 58.

77 En 1948 un kilo de café natural valía en Vigo, a precio de tasa, 40 pesetas; en 1950 había subido hasta las 70. Lógicamente el de estraperlo era más caro. En los años cuarenta el kilo de azúcar osciló entre las cuatro y las seis pesetas (a 18 el de estraperlo). Si tenemos en cuenta que el salario de un marinero en 1945 era de 9 pesetas al día y el de un trabajador agrícola era de 11 pesetas en 1950, comprenderemos mejor la importancia de esas remesas que llegaban de Brasil. Cf. Giráldez Lomba, Sobrevivir, pp. 344-45. Vid. también R. Izquierdo Perrín, España años cuarenta. Hambre, racionamiento, estraperlo. Bilbao: Eds. Beta, III Milenio 2008, pp. 21 y ss., y R. Abella, Crónica de la posguerra, 1939-1955. Barcelona, Eds. B, 2008, pp. 127 y ss. 
daba también la oportunidad de lucir galas no acostumbradas en el día a día aldeano, en especial en las ocasiones solemnes del año, que en esta época y lugar coinciden fundamentalmente con la fiesta del patrono del barrio, San Bieito, y de la parroquia, Santo André y Nosa Sra. das Dores. Para tales ocasiones llegan las prendas de vestir que ya hemos mencionado, pero también anillos (1947) y pendientes (1949), a los que se unen paraguas y relojes. Otros objetos dignos de mención son tijeras, jabón, que por falta de materias primas para ser elaborado también escaseaba, ${ }^{78} \mathrm{e}$ incluso, en una ocasión, medicamentos que en España no se encontraban (1953).

Vestidas, calzadas, alimentadas, modestamente engalanadas y con ingresos complementarios de numerario para atender a gastos perentorios, sin duda la relación con Brasil, y en menor medida, con Buenos Aires, reportó durante casi dos décadas a la familia de Galicia una situación favorable que ayudó a sobrellevar mejor las duras condiciones de vida la campesina. No puede extrañar que la muerte de Emilia trajera consigo un cambio dramático en la situación, pues desaparece su principal valedora en un momento que coincide con el cambio de coyuntura económica en Brasil y Argentina y el aumento de los gastos en Galicia, fruto tanto de la presión fiscal como de las enfermedades que comienzan a padecer las cuatro mujeres. En efecto, muchas familias, y desde luego es el caso de la nuestra, lejos de experimentar una mejoría paulatina en sus condiciones de vida, en especial durante los felices sesenta, tuvieron que vivir las estrecheces y dificultades que en América imponían las nuevas circunstancias económicas marcadas por la recesión, que de este modo prolongaba sus duros efectos hasta las tierras del Noroeste peninsular, a donde llegaban siguiendo la misma senda por donde antaño entrara la prosperidad.

\section{6. ... Y LOS DE ACÁ}

Buena parte de los estudios realizados hasta la fecha terminan aquí su análisis económico silenciando el hecho de que los envíos por el Atlántico no tuvieron lugar en una única dirección, pues no carecieron de reciprocidad. ${ }^{79}$ En efecto, los que permanecieron en el domicilio familiar no se limitaron a pedir y a aceptar, sino que en

\footnotetext{
${ }^{78}$ González Leirós, “Expansión”, p. 388.

${ }^{79}$ Soutelo Vázquez, "Proyectos migratorios”, pp. 128-30.
} 
la medida de sus posibilidades, y tal y como mandaba la rigurosa cortesía campesina, correspondieron a la generosidad de sus parientes emigrados. Ciertamente no mataron hambre, ni cubrieron desnudeces, ni facilitaron la posibilidad de lucir un modesto acicalamiento extraordinario, pero contribuyeron a matar saudades y a mantener pautas culturales que gracias a ellos arraigaron firmemente en la siguiente generación. Estos envíos podemos dividirlos en dos categorías bien diferenciadas; los espontáneos y los que se hacen por encargo de los residentes en el Nuevo Mundo.

Los primeros están compuestos casi exclusivamente por productos de la matanza del cerdo, entre los que destacan los distintos tipos de embutido y los pedazos de jamón. A estos se unen más esporádicamente trozos de tocino o cacheira (cabeza del cerdo), sin duda menos apreciados y más difíciles de enviar por su mayor dimensión y peor capacidad para ser disimulados en los equipajes para escapar al control de los aduaneros. A pesar de la mala conciencia que causa su recepción ("a ustedes les hace más falta", "non queremos que pasen mal por nosotros", "no manden que ahí necesitan más", "fue mucho, cuando manden sea por lembranza”), siempre son recibidos con alegría no disimulada y comentarios elogiosos, ${ }^{80}$ que no podían menos que causar en los remitentes un doble sentimiento: de orgullo por la valoración de su trabajo y de satisfacción por crearles conciencia de que también ellos tenían con qué corresponder y retribuir la generosidad de los de allá; por eso continuarán llegando de forma regular a lo largo del tiempo... siempre que no falte portador, lo que, como ya vimos, será cada vez más difícil. Es imposible evaluar con exactitud la composición de estas remesas, pues casi siempre se alude de forma genérica a su contenido, pero su monto general se distribuye de esta manera:

Años Número de envíos

\begin{tabular}{lcc}
\hline & Bahía & Buenos Aires \\
\hline $1935-1940$ & 4 & 0 \\
$1941-1945$ & 0 & 0 \\
$1946-1950$ & 9 & 0 \\
$1951-1955$ & 8 & 3 \\
$1956-1961$ & 9 & 1 \\
1972 y 1975 & 2 & - \\
\hline
\end{tabular}

80 "El cerdo debía ser muy grande, para mí es un orgullo". 
Lo que muestra este cuadro, con todas sus imperfecciones, lagunas y silencios, es que los envíos desde casa no decayeron en ningún momento, y a pesar de que desde Brasil las cosas empiezan a fallar a partir 1955, Lindaura y Lealdina nunca dejaron de cumplir con lo que entendían era su obligación para con sus sobrinos, en una mezcla de afecto y también de agradecimiento y respeto a la memoria de sus padres. ${ }^{81}$

A estos artículos se suman otros dos que, en este caso, sí son reclamados con insistencia y, en algunos momentos, con apremio: pimentón y azafrán, dos condimentos básicos para mantener el gusto tradicional en las comidas y que era imposible conseguir en Brasil desde principios de los años treinta. En efecto, desde 1931 los cambios políticos en España y Brasil, así como la gran crisis económica internacional, provocaron el desarrollo de una férrea política proteccionista por parte del país americano. Como consecuencia, el tratado comercial firmado entre ambos países en 1925 quedará sin efecto y, de este modo, productos hasta entonces exentos de gravámenes pasaron a verse cargados con fuertes aranceles aduaneros sin que las protestas de las autoridades españolas fuesen atendidas. Así hasta un total de sesenta y dos productos españoles desaparecieron literalmente del mercado brasileño, entre ellos los vinos, el azafrán y el pimentón. ${ }^{82}$ Por eso ya desde 1938 las cartas nos informan de cómo habitualmente en los equipajes que vienen de España viajan esos artículos, siempre recibidos con enorme satisfacción por su calidad superior respecto a los sucedáneos locales. ${ }^{83} \mathrm{Al}$ menos once latas de pimentón y ocho cajas de azafrán fueron enviadas sin problemas a lo largo del periodo estudiado. ${ }^{84}$ Sólo a finales de 1951 los aduaneros brasileños interceptaron un envío, que no dejaron pasar a pesar de que el portador ofreció pagar lo que pidieran. Se reenvió entonces a Buenos Aires

${ }^{81}$ Estos regalos, además del afectivo, tienen un valor económico que no puede desdeñarse. Las longanizas, que tanto se apreciaban allende el Atlántico, llegaban a pagarse a siete pesetas la unidad en Vigo durante los años cuarenta; el kilo de chorizo a quince y el de jamón a ochenta y cinco, y de este producto se enviaron "pedazos" a Bahía, al menos, en 1948, 1949 (2), 1950, 1951 (muy grande) y otro a Buenos Aires, 1952 (pesaba 3 kilos), 1953 (3), 1957 y 1959.

${ }^{82}$ C. Sixirei Paredes, "El Brasil de Vargas (1930-1945)", Tesis doctoral, Universidad Complutense, 1988, vol. I, pp. 974-975.

${ }^{83}$ Así se expresaba Emilia en julio de 1950 después de recibir dos latas de pimentón y una caja de azafrán: "aquí é o que mais se aprecia, pois o da qui parece telha moida e fai mal o estomago". Y en 1952: "Dios veña con el que estou sin nada”.

${ }^{84}$ El envío de estos productos se vio favorecido por el hecho de que los condimentos no estuvieron sometidos a racionamiento. 
por medio de una conocida que tenía aquel puerto como destino, pero estaba visto que estos condimentos habían salido de España con poca fortuna y también allí fueron localizados y decomisados, no pudiendo finalmente proporcionar las satisfacciones culinarias a que iban destinados.

Estos envíos contribuyeron a arraigar en la siguiente generación los gustos gastronómicos de sus mayores. Emilia contaba en sus cartas, sin duda para satisfacción de abuela y tías, con qué gusto se comían los niños el jamón en bocadillos y lo mucho que apreciaban los chorizos fabricados en casa y con los que su madre se había criado. Por su parte, la hija mayor tomó buena nota de las enseñanzas maternas y en carta de noviembre de 1955 solicita a sus tías que le envíen azafrán y pimentón, que ya no le queda, pues “o de aquí não vale nada, só tem gôsto de telha moída”.

Vino dulce, anís, frascos de perfume, paradójicamente algunas prenda de ropa difíciles de encontrar en Brasil, ${ }^{85}$ e incluso en una ocasión, en 1953, cerezas, completan la relación de productos remitidos desde España.

\section{CONCLUSIONES}

La correspondencia familiar, a pesar de sus limitaciones, nos permite introducirnos en el análisis de aspectos relacionados con los procesos migratorios difícilmente abordables a partir de la documentación convencional. Algunos pertenecen a la esfera de lo psicológico y lo emocional: el importante papel que jugaron no sólo para mantener unidos a los familiares que se habían visto separados por el éxodo, sino también para integrar en el grupo a las nuevas generaciones que iban naciendo, tanto en América como en Galicia. Pero además la información que contienen facilita también al historiador la comprensión de lo decisivas que fueron las remesas de dinero, ropas y alimentos desde ambas orillas del Atlántico, tanto para equilibrar las deficitarias economías campesinas durante los duros tiempos de la posguerra, como para que los emigrantes y sus descendientes conservaran determinadas pautas culturales, que contribuyen a mantener rasgos esenciales de la personalidad del colectivo en las sociedades de acogida.

85 "una camiseta meia [...] se llama camiseta de verán sin manga [...] aquí las tiene pero muy ordinarias". 
Por otra parte, esta documentación nos ayuda a entender que muchas veces no podemos sin más aplicar mecánicamente análisis a la realidad gallega en función de los parámetros económicos vigentes en la Península, sin tener en cuenta la evolución de la coyuntura de aquellas economías de ultramar de las que habían sido dependientes durante décadas. 


\section{APÉNDICE ESTADÍSTICO}

Remesas de dinero enviadas desde Brasil y Argentina (1936-1962)

\begin{tabular}{|c|c|c|c|}
\hline Años & \multicolumn{2}{|c|}{ Brasil } & Argentina \\
\hline 1936 & 150 & & \\
\hline 1937 & 250 & & \\
\hline 1938 & Sin especificar & & \\
\hline $1939-1942$ & No constan & & \\
\hline 1943 & & 600 & \\
\hline 1944 & & 600 & \\
\hline 1945 & & 600 & \\
\hline 1946 & & 600 & \\
\hline 1947 & & 600 & \\
\hline 1948 & & 600 & \\
\hline 1949 & 1000 & 600 & \\
\hline 1950 & 1500 & - & \\
\hline 1951 & - & - & \\
\hline 1952 & 500 & - & 500 \\
\hline 1953 & Sin especificar & - & Sin especificar cantidad \\
\hline 1954 & - & - & 2 envíos (sin especificar) \\
\hline 1955 & - & - & 100 pesos argentinos \\
\hline 1956 & - & - & - \\
\hline 1957 & - & 600 & 100 pesetas \\
\hline 1958 & 1000 & 600 & - \\
\hline 1959 & 500 & 600 & - \\
\hline 1960 & - & 600 & - \\
\hline 1961 & - & 600 & - \\
\hline 1962 & & 600 & 1000 pesos $=607$ pesetas \\
\hline
\end{tabular}

